\title{
Characterization of Mould in Masonry in Hospital Environment-Case Study
}

\author{
Washington Batista de Souza, Adalberto Matoski \\ Universidade Tecnológica Federal do Paraná, Curitiba, Brazil \\ Email: wbsengenharia@gmail.com, Adalberto@utfpr.edu.br
}

How to cite this paper: de Souza, W.B. and Matoski, A. (2016) Characterization of Mould in Masonry in Hospital Environment-Case Study. Open Journal of Civi Engineering, 6, 618-630.

http://dx.doi.org/10.4236/ojce.2016.64050

Received: July 22, 2016

Accepted: September 18, 2016

Published: September 21, 2016

Copyright $\odot 2016$ by authors and Scientific Research Publishing Inc. This work is licensed under the Creative Commons Attribution International License (CC BY 4.0).

http://creativecommons.org/licenses/by/4.0/

\begin{abstract}
The objective of this study is the characterization of mould inside and in the surface wall of a hospital. The present research was made on the wall of the Clinical Hospital of the Federal University of Paraná, Brazil. For the methodology the samples were extracted from the surface, mortar and brick. The samples were spread on Petri plates containing Sabouraud dextrose agar and incubated at $25^{\circ} \mathrm{C}$ for seven days. The results of the 90 samples collected showed growth of $39 \%$ of colonies with the following distribution of microorganisms: Aspergillus (present in 27\% of samples), Cladosporium, Absidia, Rhizopus, Rhodotorula, Fusarium, Penicillium and Aspergillus flavus. Within the investigated substrate, three species of different fungi were identified: Aspergillus flavus, Aspergillus fumigatus and Aspergillus niger.
\end{abstract}

\section{Keywords}

Walls, Brick, Mould, Mortar, Hospital

\section{Introduction}

The study of mold growth in the walls interior of masonry, particularly fungi present in grout coatings, is necessary whereas in a wall demolition process, possible fungal spores, that may be latent inside, can contaminate the environment. If the demolition is conducive to the contamination of air, these spores can be inhaled by immunocompromised patients who do not offer resistance to reproduction, which in turn provide favorable conditions of temperature, humidity and substrates for growth as analysis of Zanon and Alves [1].

The fungi of genre Aspergillus, cause of aspergillosis, have the rapid growth at temperature near $37^{\circ} \mathrm{C}$, which coincides with the range of variation of body temperature. The fungal spores can lodge, in some cases, in the brain region, or even in the lungs where they multiply cause infection that causes damage to the affected organ and en- 
hances the appearance of other diseases such as tuberculosis and pneumonia, cited for

[2] or the study of [3].

Studies have reported a significant increase in patients who developed aspergillosis associated with periods when remodeling and construction of the hospital environment and its proximity are conformed [4].

In regions such as Thailand, for example, fungus infection ranking third after frequent cause of diseases such as tuberculosis and cryptococcosis in HIV (Human Immunodeficiency Virus) confirmed the development as studies of Ranjana et al. [5].

Filamentous fungi of the Aspergillus genre are opportunistic. These are the most cited in the literature and are the most common in transplant patients of bone marrow and neutropenic or studies of [6].

In turn, research on fungal nutrition in building materials indicates that the salt content and the moisture present in the mortar can influence the growth of fungi [7].

Fungi can absorb nutrients present in building materials. The main nutrients are those derived from petroleum hydrocarbons which may be adhered to the concrete, mortar and other materials [8].

So in the interest of identifying the fungi that may be present in different environments, this study aims to characterize fungi in two different regions of a hospital environment.

\section{Methodologies}

Curitiba's Clinical Hospital-HC is located in the city of Curitiba, Brazil.

For the research we chose two monitored environments: the laundry and the central warehouse. Samples collected from the mortar coatings interior and ceramic block settlement were subject to the following:

1. Growing fungi present in samples for the purpose of verification and quantification of them;

2. Grip analysis;

3. Determination of the specific mass of the sample;

4. Identification of the moisture content of the samples;

5. Determination of the $\mathrm{pH}$ of the samples;

6. Checking the level of carbonation of the samples.

\subsection{Sample Collection and Fungi Growing}

According to the determination of [9], two samples were collected from the air inside the laundry room and one from the outdoor of the laundry environment. For warehouse study, four samples were collected from the indoor air and one from outdoor air of the warehouse.

For the removal of samples from the surface regions of the walls the recommendations [10], were used as a parameter, which standardizes the minimum number of samples to be analyzed by the environment. Through Equation (1) the number of points (Ni) to be measured in the laundry room and warehouse was calculated (shed No. 2). 
Thus, for laundry $\mathrm{Ni}$ used was equal to two and for the storeroom $\mathrm{Ni}$ was equal to three.

$$
\mathrm{Ni}=0.15 \sqrt{\mathrm{Ai}}
$$

Taking into consideration the total area of the hospital equal to $62,000 \mathrm{~m}^{2}$, the minimum total number of samples to be analyzed is equal to 38 .

Therefore, during this paper a total of 30 samples from laundry and 60 from warehouse were collected in Table 1.

The methodology of testing consists of collecting a sample of the internal and the external air from the researched environment following the prescribed parameters described in the [9].

The plate was incubated in a greenhouse at $25^{\circ} \mathrm{C} \pm 3^{\circ} \mathrm{C}$ for seven days, after which incubation period the plate was removed from the oven and the reading of the colonies of fungi was performed. At this stage fungal species that grew on the plate, as well as the number of colonies found were observed.

For the collection of surface samples (on the coating) the following procedures were performed:

1. Use of RODAC ${ }^{\oplus} 7$ type contact plate of $25 \mathrm{~cm}^{2}$ surface for sample collection.

2. Collection of samples through the opening in the contact plate for a few seconds. Therefore, the plate was pressed against the wall surface.

3. At the laboratory the plates were incubated at $25^{\circ} \mathrm{C}$ for seven days after which the incubation period the samples were removed from the oven and the same reading was taken.

4. Sowing the collected material was performed with swab on plates containing $1 \mathrm{~g}$ of material.

To collect the samples inside the mortar, the following procedures were performed:

1. Scraping the surface of the sample collection point. An alcohol sterilized slitter which went through a portable torch flame was used to extract the sample to be analyzed.

2. Using a sterilized drill bit, drilling the scaling point was taken until reaching a maximum depth of $25 \mathrm{~mm}$, which corresponds to the average depth of the mortar

Table 1. Illustration of the number of samples taken for each substrate and for each location that is the laundry and the warehouse.

\begin{tabular}{cccc}
\hline Region & \multicolumn{3}{c}{ Substrate } \\
\cline { 2 - 4 } & Surface & Mortar & Ceramic Block \\
\hline South Laundry-Region A & 05 & 05 & 05 \\
North Laundry-Region B & 05 & 05 & 05 \\
North Warehouse-Region C & 05 & 05 & 05 \\
East Warehouse-Region D & 05 & 05 & 05 \\
West Warehouse-Region E & 05 & 05 & 05 \\
South Warehouse-Region F & 05 & 05 & 05 \\
Total & 30 & 30 & 30 \\
\hline
\end{tabular}


coating. After removal of the inner wall of the drill a quantity of sample was collected with the aid of a swab.

3. Using a sterilized loop 1g material was collected for later sowing in a Petri plate containing ASD.

4. After the period of incubation the sample was taken for analysis and characterization of the colonies formed.

To collect samples from the brick the following procedures were performed:

1. The samples were removed from the ceramic block inside the wall in a manner similar to that adopted for the collection of the mortar coating.

2. The wall drilling depth to extract only the ceramic block sample varied from 30 to $40 \mathrm{~mm}$.

3. The procedures for the identification, transportation and opening the sterile flasks were the same as described in the collection of mortar samples.

\subsection{Fungi Identification}

The determination of fungi is by macroscopic and microscopic morphological comparison is performed through literatures, and reference material. In determining the genres are used the Bunsen burner, a Petri dish, sterile handle, blade, glass slides, ASD means to $4 \%$ lactophenol cotton blue dye and, as a reagent, distilled water.

In the cultivation method in the Petri dish blade should be capped and left seven to ten days in an oven at $25^{\circ} \mathrm{C} \pm 3^{\circ} \mathrm{C}$. After this period the cover slip is removed with the aid of gripper carefully, as there should be adhered hyphae and fungal spores. Then, a drop of lactophenol cotton blue dye is dripped and Agar hub is discarded and then replaced by another drop of dye that must cover the entire glass slides. Thus, hyphae and spores adhered to the blade can be viewed.

In the final stage of the cultivation procedure, the blade should be sealed with transparent enamel and observed with an optical microscope with 40X objective magnification. The identification of the microorganism is carried out by evidence of dimorphism and the characteristic microscopic appearance of each phase [11].

In this work the counting of fungal colonies found was performed manually, and the identification of the microorganisms was carried out by means of an optical microscope.

\subsection{Adhesion, Moisture Content, $\mathrm{pH}$ and Carbonation}

For the adhesion test 12 samples were selected by the area studied, similar to recommended by the American Standard Test Method in its document [12]. Thus, a total of 60 samples were subjected to the adherence test.

The samples used in the breeding ground and the grip tests were taken from the same wall where the samples were collected for fungi cultivation tests. The drillings on the wall were performed dry, but the law also suggests that drillings are made by moistening the saw cup. For $\mathrm{pH}$ test samples were taken from mortar powder of the six researched regions. Samples were taken from the same points where the materials were 
removed for the breeding ground.

For testing the degree of carbonation three specimens were extracted by researched region.

\section{Results}

\subsection{Fungi Identification}

The incidence of fungi in the air collected by the [13] type sampler, from the laundry interior can be shown in Table 2 .

In Table 2 we can observe that the region B (the north facade) shows a higher concentration of molds $\left(350 \mathrm{CFU} / \mathrm{m}^{3}\right)$, but is still lower than $750 \mathrm{CFU} / \mathrm{m}^{3}$ per sample collected as limit established by [9].

The results presented in Table 3 indicate that there is need for cleaning of the internal environment as compared to the amount found between the two environments is greater than recommended by ANVISA.

\subsection{Identification of Fungi in the Laundry}

The percentage of fungal growth on the 30 samples collected in laundry and placed in Petri dishes was $80 \%$, which can be explained by the fact that the laundry room had a relative air humidity average of $60 \%$ and temperatures above $25^{\circ} \mathrm{C}$ during the day. Such environmental conditions are favorable to the growth of microorganisms and justify the results found that $64 \%$ of the samples had fungi.

Table 2. Incidence of fungi in indoor air laundry.

\begin{tabular}{cccccc}
\hline $\begin{array}{c}\text { Region A (South) } \\
\text { Fungi }\end{array}$ & $\begin{array}{c}\text { Occur. } \\
\text { Col/plate }\end{array}$ & $\begin{array}{c}\text { Quant. } \\
\text { UFC/m }\end{array}$ & $\begin{array}{c}\text { Region B (North) } \\
\text { Fungi }\end{array}$ & $\begin{array}{c}\text { Occur. } \\
\text { Col/plate }\end{array}$ & $\begin{array}{c}\text { Quant. } \\
\text { UFC/m }\end{array}$ \\
\hline Absidia spp & 6 & 21 & Absidia spp & 3 & 21 \\
Aspergillus spp & 6 & 21 & Alternaria spp & 1 & 4 \\
Cladosporium spp & 17 & 60 & Aspergillus spp & 5 & 21 \\
Fusarium spp & 1 & 4 & Cladosporium spp & 13 & 60 \\
Penicillium spp & 63 & 222 & Fusarium spp & 1 & 4 \\
Subtotal & 93 & 328 & Penicillium spp & 76 & 222 \\
\hline
\end{tabular}

Table 3. Incidence of fungi in the outside air of the laundry.

\begin{tabular}{ccc}
\hline $\begin{array}{c}\text { External Area HC } \\
\text { Fungi }\end{array}$ & $\begin{array}{c}\text { Occur. } \\
\text { Col/plate }\end{array}$ & $\begin{array}{c}\text { Quant. } \\
\text { UFC } / \mathrm{m}^{3}\end{array}$ \\
\hline Aspergillus spp & 7 & 25 \\
Cladosporium spp & 13 & 46 \\
Fusarium spp & 1 & 4 \\
Penicillium spp & 7 & 25 \\
Subtotal & 28 & 99 \\
\hline
\end{tabular}


The results from samples collected from the surface regions of laundry allowed to identify seven different fungi (Table 3). It is observed that these fungi found are common in this type of environment. Inside the mortar of researched laundry points the fungus Aspergillus flavus and also filamentous fungi which were not identified were found. The incidence of these fungi occurred only in the northern region B laundry.

Considering samples which presented fungi in their results, the following was observed: the more common fungi in surface were: Absidia (26\%), Cladosporium (21\%) and Aspergillus (18\%) and being the rest 33\% relative to fungi with less incidence. In turn, in the mortar: Aspergillus (28\%), A. flavus and Penicillium (34\%) and $38 \%$ are of less incidence fungi. In the ceramic block the fungi found were: Fusarium and Rhodotorulla (44\%).

Table 4 shows the average quantities and fungal CFU per dot formed in each searched laundry region.

\subsection{Warehouse}

A total of five samples from ambient air were collected, being four samples of the air present within the warehouse and one from outside air of the warehouse environment. 60 samples of substrates were also collected: 20 from the surface of the walls regions, inside the 20 from the coating mortar and 20 from ceramic blocks located inside the wall of the warehouse in Clinical Hospital.

Table 5 shows the results obtained from the analysis of the incidence of fungi in indoor air of the Regions C (north facade) and D (east facade) of the warehouse.

Table 5 shows that the region $\mathrm{C}(\mathrm{N})$ is the one that has a higher concentration of fungi $\left(562 \mathrm{CFU} / \mathrm{m}^{3}\right.$ ), but still is lower than $750 \mathrm{CFU} / \mathrm{m}^{3}$ per sample collected.

Table 4. Fungi occurred in the laundry.

\begin{tabular}{|c|c|c|c|c|c|c|}
\hline \multicolumn{7}{|c|}{ Local Substrates Survey } \\
\hline Region & $\begin{array}{l}\text { Surface } \\
\text { Fungi }\end{array}$ & $\begin{array}{c}\text { Occur. } \\
\text { UFC/plate }\end{array}$ & $\begin{array}{c}\text { Mortar } \\
\text { Fungi }\end{array}$ & $\begin{array}{l}\text { Occur. } \\
\text { UFC/g }\end{array}$ & $\begin{array}{c}\text { Ceramic block } \\
\text { Fungi }\end{array}$ & $\begin{array}{l}\text { Occur. } \\
\text { UFC/g }\end{array}$ \\
\hline & Absidia & 6 & Aspergillus & 101 & Aspergillus & 3 \\
\hline & Aspergillus & 39 & A. flavus & 7 & A. niger & 1 \\
\hline & Cladosporium & 61 & Cladosporium & 1 & Fusarium & 6 \\
\hline & Fusarium & 5 & Fusarium & 12 & & \\
\hline & Penicillium & 3 & Penicillium & 1 & & \\
\hline & Rhizopus & 2 & Rhodotorulla & 8 & & \\
\hline & Rhodotorulla & 2 & & & & \\
\hline & Absidia & 5 & Aspergillus & 63 & Absidia & 1 \\
\hline & Aspergillus & 131 & Filamentous $\mathrm{f}$. & 200 & Aspergillus & 1 \\
\hline \multirow[t]{3}{*}{ B } & Cladosporium & 147 & Penicillium & 2 & A. fumigatus & 1 \\
\hline & Fusarium & 7 & Rhodotorulla & 1 & Rhodotorulla & 2 \\
\hline & Rhodotorulla & 2 & & & & \\
\hline
\end{tabular}


Table 5. Incidence of fungi in indoor air of the warehouse-Regions C and D.

\begin{tabular}{cccccc}
\hline $\begin{array}{c}\text { Region C (North) } \\
\text { Fungi }\end{array}$ & $\begin{array}{c}\text { Occur. } \\
\text { Col/plate }\end{array}$ & $\begin{array}{c}\text { Quant. } \\
\text { UFC/m }\end{array}$ & $\begin{array}{c}\text { Region D (East) } \\
\text { Fungi }\end{array}$ & $\begin{array}{c}\text { Occur. } \\
\text { Col/plate }\end{array}$ & $\begin{array}{c}\text { Quant. } \\
\text { UFC } / \mathrm{m}^{3}\end{array}$ \\
\hline Absidia spp & 1 & 21 & Absidia spp & 3 & 11 \\
Aspergillus spp & 84 & 297 & Aspergillus spp & 24 & 85 \\
Cladosporium spp & 74 & 222 & Cladosporium spp & 25 & 88 \\
Subtotal & 159 & 562 & Subtotal & 52 & 184 \\
\hline
\end{tabular}

Table 6 displays the analyses results of indoor air of the Regions $\mathrm{E}$ (west) and F (south) of the warehouse

All fungi found in the air in the west and south facades of the warehouse are present in concentrations within the tolerated limit. All of these fungi are common to the type of the evaluated environment (warehouse), except for the fungus Absidia.

Table 7 shows the results obtained in the measurements of the air outside the warehouse.

The incidence of fungi observed in 60 Petri dishes with samples collected from the warehouse was $50 \%$ for all surveyed substrates.

The greater incidence of fungi in the warehouse occurred in masonry surface region, followed by mortar and, finally, the ceramic block.

Only the northern region justified the need for internal cleaning by using the ratio of $\mathrm{CFU} / \mathrm{m}^{3}$ (or recommended maximum) obtained between internal and external environment.

In relation to environmental conditions, the warehouse had a relative humidity of the air average of $65 \%$. The average temperature inside the warehouse environment was $22^{\circ} \mathrm{C}$ in winter and $27^{\circ} \mathrm{C}$ in summer. Both temperature and the relative humidity of the air registered may favor the formation of colonies on the surface of masonry. This situation was similar to that found in the laundry room.

\section{Presence of Fungi in the Substrates Investigated in Warehouse}

The incidence of fungi in the researched areas was $100 \%$ of the locals from all regions researched in the warehouse. This finding can be explained mainly by the lack of hygiene and the humidity rate and temperature found.

Table 8 shows the fungus and the average amount of CFU formed by local studied in each warehouse area

The results from samples collected from the surface regions in the warehouse allowed to identify eight fungus species.

Inside the mortar of the warehouse researched sites the following fungi were found: Rhodotorulla and Absidia. The incidence of these fungi occurred only in the Northern Region of the warehouse.

On the surface the fungi most frequently found were: Absidia, Aspergillus, Cladosporium and Rhizopus (20\%), while in the mortar: Aspergillus (60\%) and last in the ceramic block: Aspergillus (67\%). 
Table 6. Incidence of fungi in indoor air of the warehouse-Regions E and F.

\begin{tabular}{cccccc}
\hline $\begin{array}{c}\text { Region E (West) } \\
\text { Fungi }\end{array}$ & $\begin{array}{c}\text { Occur. } \\
\text { Col/plate }\end{array}$ & $\begin{array}{c}\text { Quant. } \\
\text { UFC/m }\end{array}$ & $\begin{array}{c}\text { Region F (South) } \\
\text { Fungi }\end{array}$ & $\begin{array}{c}\text { Occur. } \\
\text { Col/plate }\end{array}$ & $\begin{array}{c}\text { Quant. } \\
\mathrm{UFC} / \mathrm{m}^{3}\end{array}$ \\
\hline $\begin{array}{c}\text { Absidia spp } \\
\text { Aspergillus spp }\end{array}$ & 2 & 7 & Absidia spp & 1 & 4 \\
Cladosporium spp & 52 & 154 & Aspergillus spp & 29 & 102 \\
Rhizopus spp & 1 & 4 & Cladosporium spp & 12 & 42 \\
Subtotal & 70 & 248 & Shizopus & 1 & 4 \\
\hline
\end{tabular}

Table 7. Fungi incidence in the air outside the warehouse.

\begin{tabular}{ccc}
\hline External Area HC Fungi & Occur. Col/plate & Quant. UFC/ $\mathrm{m}^{3}$ \\
\hline Aspergillus spp & 15 & 53 \\
Cladosporium spp & 30 & 106 \\
Penicillium spp & 17 & 60 \\
Subtotal & 62 & 219 \\
\hline
\end{tabular}

Table 8. Fungi incidence in the warehouse.

\begin{tabular}{|c|c|c|c|c|c|c|}
\hline \multicolumn{7}{|c|}{ Local Substrats Survey } \\
\hline Region & $\begin{array}{l}\text { Surface } \\
\text { Fungi }\end{array}$ & $\begin{array}{l}\text { Occur. } \\
\text { UFC/plate }\end{array}$ & $\begin{array}{c}\text { Mortar } \\
\text { Fungi }\end{array}$ & $\begin{array}{l}\text { Occur. } \\
\text { UFC/g }\end{array}$ & $\begin{array}{c}\text { Ceramic block } \\
\text { Fungi }\end{array}$ & $\begin{array}{l}\text { Occur. } \\
\text { UFC/g }\end{array}$ \\
\hline & Absidia & 4 & Absidia & 2 & Rhodotorulla & 1 \\
\hline & Aspergillus & 81 & Aspergillus & 1 & & \\
\hline & Cladosporium & 84 & Rhodotorulla & 1 & & \\
\hline & Fusarium & 1 & & & & \\
\hline & Rhodotorulla & 1 & & & & \\
\hline & Absidia & 4 & & & & \\
\hline & Aspergillus & 43 & & & & \\
\hline \multirow[t]{6}{*}{$\mathrm{D}$} & Cladosporium & 114 & & & & \\
\hline & Rhizopus & 3 & & & & \\
\hline & Rhodotorulla & 1 & & & & \\
\hline & Absidia & 5 & Aspergillus & 1 & Aspergillus & 3 \\
\hline & Aspergillus & 41 & & & A. niger & 1 \\
\hline & A. fumigatus & 1 & & & & \\
\hline \multirow[t]{5}{*}{$\mathrm{E}$} & Cladosporium & 104 & & & & \\
\hline & Penicillium & 1 & & & & \\
\hline & Rhizopus & 12 & & & & \\
\hline & Rhodotorulla & 7 & & & & \\
\hline & Absidia & 4 & Aspergillus & 1 & Aspergillus & 2 \\
\hline \multirow[t]{2}{*}{$\mathrm{F}$} & Aspergillus & 32 & & & & \\
\hline & Cladosporium & 68 & & & & \\
\hline
\end{tabular}




\subsection{Physical and Mechanical Characterization of Mortar}

Tests to check the resistance, adhesion, moisture content and the density of the coating mortar of each region of the study sites were made. A comparison of the results found in all the researched facades is shown in Figure 1.

It is observed that in the laundry moisture content is the highest of all what justifies the amount of mold in this region which was higher than that found in the warehouse

In Figure 2 is shown a comparison of the values of tensile strength at maximum, minimum and average traction in $\mathrm{MPa}$ found in four of the six regions of the environments studied.

The region $\mathrm{A}$ is not included in Figure 2 for presenting tensile strength equal to zero, so it was not possible to perform the tensile test because the degree of deterioration of this mortar caused by the presence of fungi.

\section{5. pH Assay}

The results obtained for the $\mathrm{pH}$ of the surveyed areas of the mortar are shown in Table 9.

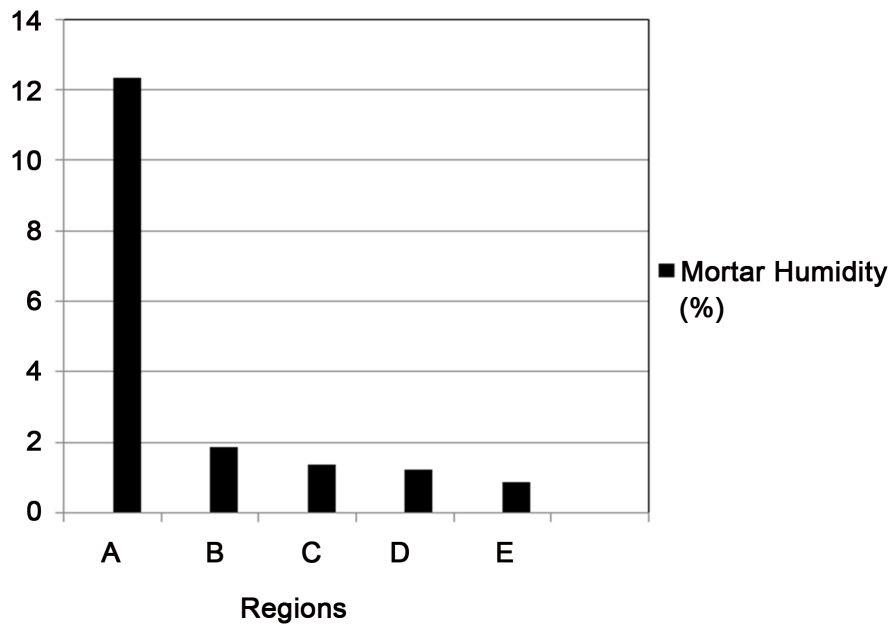

Figure 1. Moisture content.

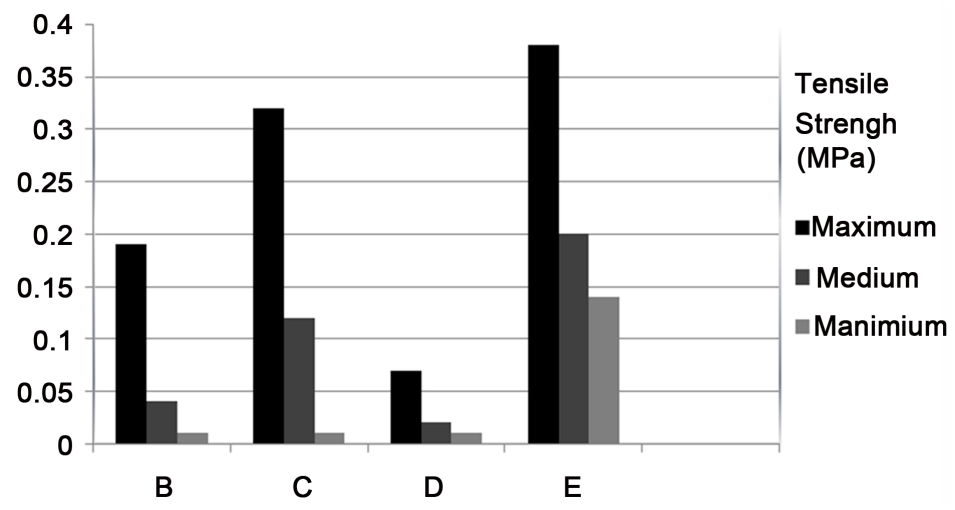

Figure 2. Tensile strength of the coating mortar. 
Table 9. Results of the $\mathrm{pH}$ found in mortar samples.

\begin{tabular}{ccc}
\hline Region & Facade & $\mathrm{pH}$ \\
\hline A & South-Laundry & 9.22 \\
B & North-Laundry & 9.10 \\
C & North-Warehouse & 8.88 \\
D & East-Warehouse & 9.56 \\
E & West-Warehouse & 9.28 \\
F & South-Warehouse & 10.80 \\
\hline
\end{tabular}

The results shown in Table 9 were obtained using a digital ph meter. These values indicate a low alkalinity and is another factor favoring the growth of fungi. The test samples were carbonated, thus justifying the reduction of $\mathrm{pH}$.

\section{Discussion}

\subsection{Incidence of Fungi}

Although the results of fungi found in ambient air of the researched areas were below the limit value of $750 \mathrm{CFU} / \mathrm{m}^{3}$, established by normative resolution [9], the RMV (Recommended Maximum Value) which compares biological contamination of indoor air to the outside air, in both regions ( $\mathrm{A}$ and $\mathrm{B}$ ) of the laundry and the $\mathrm{C}$ region of the warehouse, exceed the limit value of 1.5 colonies forming units required by [9]. This can be explained in the case of laundry because the ventilation of the room was poor and the high moisture content found in the mortar.

According to the results shown in Table 3 it is possible to observe the occurrence of seven different fungi identified on the surface of the masonry and all these fungi were found in the inside air of the laundry except Rhodotorulla and Rhizopus.

The fungus Aspergillus niger was found only within the ceramic block and Aspergillus flavus only within the mortar. The fungus Alternaria appeared only in ambient air.

Into the mortar were found different fungi and other filamentous fungi without identification, among the identified stand Aspergillus, Fusarium and Penicillium.

For laundry is also important to note that only one of the sites researched from ceramic block was negative for the occurrence of fungi.

The presence of Aspergillus in $44 \%$ of all fungi found in the mortar substrate samples in the laundry and $60 \%$ for the warehouse was verified.

Two of the fungi genres considered opportunistic to immunocompromised patients were found in these environments exceeding the recommended amount: Aspergillus and Cladosporium. Among the results obtained to the warehouse the fungus Aspergillus niger stands out which was found in a sample of the ceramic block in one of the researched areas. In contrast to laundry, in the warehouse a larger number of mold growth was found in ceramic block in relation to the mortar substrate. This result can be explained by the warehouse mortar be about 50 years younger than the mortar present in the laundry room. 
The presence of fungi was observed at all sites of all warehouse areas analyzed. The highest incidence of fungi was observed on the west front that has lower heat stroke when compared to north façade, for example, and is located next to a landfill, a condition that may have allowed for poor sealing the passage of moisture and nutrients necessary for fungal proliferation in this site.

In the laundry room $80 \%$ of the samples tested positive for fungi. Already, in the warehouse the percentage of positive samples was equal to $50 \%$. The difference between the results of positive samples found can be associated to the ambient conditions for each evaluated environment. In the laundry room more favorable environmental conditions for the proliferation of fungi were observed.

\subsection{Number of Colonies}

Some of the 53 positive samples for mold growth are distinguished by the amount of CFU observed. The number five sites (south facade) and sites one and three (north facade) from laundry showed more than $100 \mathrm{CFU} /$ plate (Aspergillus), and also more than $100 \mathrm{CFU} /$ plate (filamentous fungi), respectively.

Considering this results in CFU/dm ${ }^{2}$, we have an approximate value of $25 \mathrm{CFU} / \mathrm{dm}^{2}$, a result considered above European standards for contamination of clean surfaces as the European Technical Standard [14].

In the case of warehouse site number three (west facade) showed the highest growth of fungi (16 CFU/plate).

In the mortar concentrations were observed over $50 \mathrm{CFU} / \mathrm{g}$ for filamentous fungi and the incidence of $A$. fumigatus within the ceramic block was observed.

This corroborates with results presented by studies linking invasive aspergillosis with reforms involving demolitions, since in these cases there is usually an increased concentration of this fungus in the air which enables the development of the disease.

\subsection{Moisture Content}

The coefficient of variation (CV) of the moisture content found at $20 \mathrm{~cm}$ was $7.79 \%$ for all samples, and $10.59 \%$ for the collection made at $90 \mathrm{~cm}$ from the floor. Thus, the samples showed a reliable variation coefficient considering the amount of selected samples in accordance with the recommendations made by other studies. Samples collected at $20 \mathrm{~cm}$ from the floor have an excessive amount of moisture content contained in the mortar, which compromised its tensile strength and facilitated the formation of mold. This situation is confirmed even with the breeding ground tests for fungi which were positive in $100 \%$ of the samples studied for surface, $80 \%$ in mortar coating and $60 \%$ in the ceramic block samples.

The moisture content found in laundry mortar samples was higher than that found in the warehouse samples, comparing the region $\mathrm{A}$ with the other ones it reaches six times higher, as shown in Figure 1, disregarding region A, region B which is also in the laundry room was the one with the highest average moisture content, the others are in the warehouse where region $\mathrm{C}$ which has an external landfill was the one with the 
highest average value among the surveyed areas in the warehouse. In region $\mathrm{A}$, in which the moisture content was found to be higher, the growth of seven different fungi were identified on the surface, five in the mortar coating and three in the ceramic block.

\subsection{Test of Adhesion}

In the adherence test was perceived thickness of the mortar coating that ranged between 25 and $35 \mathrm{~mm}$. On this test was also observed that about $42 \%$ of the sample broke entirely and $33 \%$ broke at the start point of the adhesive along the tile characterizing mortar as substrate with adhesive rupture which received little or no roughcast.

For Laundry samples the tensile strength test showed that the formation of trace used in the evaluated coating mortar, probably had only lime and sand. This hypothesis is due to the low values found in the tensile test and is based on historical reports listed in Clinical Hospital files. According to hospital records, the mortar used in construction was produced around 1960, a time when only some regions of Brazil employed cement in the constitution of the plaster.

The mortar researched in Region B has an average tensile strength less than $0.05 \mathrm{MPa}$ and had none of their samples with the minimum required by norms. The researched regions $\mathrm{C}$ and $\mathrm{E}$ which have cement in their constitution has reached its average values above $0.1 \mathrm{MPa}$ and several samples with values greater than $0.2 \mathrm{MPa}$.

The coating mortar from Region $\mathrm{E}$ reached an average tensile strength of $0.20 \mathrm{MPa}$. Seven samples showed very similar results or above the minimum recommended by norms. These results demonstrate that the wall of the region E may be a coating mortar with consistency and resistance higher than the other regions studied.

All samples studied presented carbonated showing a relationship between the presence of fungi and the carbonation process, which reduces the $\mathrm{pH}$ of the substrate.

\section{Conclusions}

In both environments studied (laundry and warehouse), positive results were obtained for the incidence of fungi on the surface of walls, mortar coating and ceramic block. They were found in these two environments of genres considered opportunistic to immunocompromised patients in excess of the recommended: Aspergillus and Cladosporium.

Other genres found were: Aspergillus (present in 27\% of samples), Cladosporium Absidia, Rhizopus, Rhodotorula, Fusarium, Penicillium and Aspergillus flavus. Within the investigated substrate three species of different fungi were identified: Aspergillus flavus, Aspergillus fumigatus and Aspergillus niger.

For laundry the results were more expressive. This aspect was justified because the higher humidity in the laundry room, next to $12 \%$, caused the mold growth. These aspect justified the result above $100 \mathrm{CFU} / \mathrm{g}$ detected on a board.

The biodeterioration that caused the disintegration of the substrate did not allow the extraction of samples for tensile strength test. All researched areas present mortar samples which are fully carbonated. 


\section{References}

[1] Zanon, U. and Neves, J. (1987) Infecções Hospitalares-Prevenção, Diagnóstico e Tratamento. MEDSI, Rio de Janeiro.

[2] Del Palacio, A., Cuetara, M.S. and Ponton, J. (2003) Invasive Aspergillosis. Revista Iberoamericana de Micología, 20, 77-78.

[3] Bhabhra, R. and Askew, D.S. (2005) Thermotolerance and Virulence of Aspergillus fumigatus: Role of the Fungal Nucleolus. Medical Mycology, 43, 87-93. http://dx.doi.org/10.1080/13693780400029486

[4] Curtis, L., Cali, S., Conroy, L., Baker, K., Ou, C.H., Hershow, R., Norlock-Cruz, F. and Scheff, P. (2005) Aspergillus Surveillance Project at a Large Tertiary-Care Hospital. Journal of Hospital Infection, 53, 188-196. http://dx.doi.org/10.1016/j.jhin.2004.05.017

[5] Ranjana, K.H., Priyokumar, K., Singh, T.J., Gupta, C.C., Sharmila, L., Singh, P.N. and Charkrabartl, A. (2002) Disseminated Penicillium marneffei Infection among HIV-Infected Patients in Manipur State, India. Journal of Infection, 45, 268-271. http://dx.doi.org/10.1053/jinf.2002.1062

[6] Richardson, M.D. and Warnock, D.W. (2003) Fungal Infection Diagnosis and Management. 3rd Edition, Blackwell Publishing Ltd., Oxford.

[7] Singh, J., Yu, C.W.F. and Kim, J.T. (2010) Building Pathology, Investigation of Sick Buildings-Toxic Moulds. International Society of the Built Environment, Londres.

[8] Shirakawa, M.A., Beech, I.B., Tapper, R., Cincotto, M.A. and Gambale, W. (2003) The Development of a Method to Evaluate Bioreceptivity of Indoor Mortar Plastering to Fungal Growth. International Biodeterioration \& Biodegradation, 51, 83-92. http://dx.doi.org/10.1016/S0964-8305(01)00129-9

[9] ANVISA (Agência Nacional de Vigilância Sanitária Brasileira) (2003) Padrão Brasileiro de Microbiologia-Resolução 09/2003. Diário Oficial da União, Brasília.

[10] NT-SCE-02. Nota Técnica Portuguesa (2006) Metodologia para auditorias periódicas de qualidade do ar interior em edifícios de serviços existentes no âmbito do RSECE, Portugal.

[11] American Public Health Association (2012) Microbiological Examination of Water. In: Standard Methods for the Examination of Water and Wastewater, Method 9215-B, 22nd Edition, American Public Health Association, Washington DC.

[12] American Society for Testing and Materials (2015) ASTM D7234-12: Standard Test Method for Pull-Off Adhesion Strength of Coatings on Concrete Using Portable Pull-Off Adhesion Testers.

[13] Merck (2014) Air MAS-100: Microbiological Air Sample-Operator's Manual. Darmstadt, Germany, p. 47.

[14] (1991) NE 01-90, Guide du Bionettoyage. Official Journal French Republic, France. 
Submit or recommend next manuscript to SCIRP and we will provide best service for you:

Accepting pre-submission inquiries through Email, Facebook, LinkedIn, Twitter, etc. A wide selection of journals (inclusive of 9 subjects, more than 200 journals)

Providing 24-hour high-quality service

User-friendly online submission system

Fair and swift peer-review system

Efficient typesetting and proofreading procedure

Display of the result of downloads and visits, as well as the number of cited articles

Maximum dissemination of your research work

Submit your manuscript at: http://papersubmission.scirp.org/

Or contact ojce@scirp.org 